\title{
Liability for Environmental Damage in Portugal - A Short Overview
}

\section{Jorge Barros Mendes}

\author{
Professor at the School of Technology and Management, Polytechnic Institute of Leiria. \\ Doctor of Law student, in Public Law, Portuguese Catholic University - Oporto Law School \\ jorge.mendes@ipleiria.pt
}

\section{Doi:10.5901/mjss.2013.v4n10p439}

Abstract

The environmental law enshrined as a fundamental principle in article 66 of the Portuguese Constitution. The Environmental Liability Directive establishes a framework of environmental liability, based on the "polluter-pays" principle, to prevent and remedy environmental damage. The Decree-Law 147/2008, of 29th July came transpose into Portuguese law Directive 2004/35/EC of the European Parliament and of the Council of 21st April 2004. The Law 67/2007, of 31st December, establishing in Portugal the regime for tort liability arising from losses caused by third parties, due to the acts of public management in relation to all the functions of the State, i.e. i) administrative, ii) legislative, and iii) jurisdictional.

\section{Introduction}

The environmental law - administrative special law - is enshrined as a fundamental principle in article 66 of the Portuguese Constitution, as argued by Vasco Pereira da Silva, with a dual nature "as it presents itself simultaneously as subjective right and as a key element of objective order of the community."(Silva, 2000).

\section{The Environmental Liability Directive}

The purpose of the Environmental Liability Directive - ELD- is to establish a framework of environmental liability, based on the "polluter-pays" principle, to prevent and remedy environmental damage (Lawrence, 2013).

The ELD aims at ensuring that the financial consequences of certain types of harm caused to the environment will be borne by the economic operator who caused this harm. Insofar as the ELD provides for the financial responsibility of an operator, it lays down a framework, based on the "polluter-pays" principle, which can be qualified as one of "environmental liability", even though liability under the ELD has few in common with standard civil liability rules. For instance, the ELD does not give private parties a right of compensation as a consequence of environmental damage or of an imminent threat of such damage occurring.

The ELD's own specific approach is shown by the role given to competent authorities to be designated by Member States. These competent authorities - in the Portuguese case Environment Portuguese Agency - will ensure the effective implementation and enforcement of the ELD.

It's important to attend to the definition of environmental damage, cfr. art ${ }^{\circ} \mathrm{ELD}$.

There are three categories of environmental damage under the ELD:

a) "damage to protected species and natural habitats", which is any damage that has significant adverse effects on reaching or maintaining the favorable conservation status of such habitats or species. The habitats and species concerned are defined by reference to species and types of natural habitats identified in the relevant parts of the Birds Directive 79/409 and the Habitats Directive 92/43;

b) "water damage", which is any damage that significantly adversely affects the ecological, chemical and/or quantitative status and/or ecological potential, as defined in the Water Framework Directive 2000/60, of the waters concerned;

c) "land damage", which is any land contamination that creates a significant risk of human health being adversely affected as a result of the direct or indirect introduction, in, on or under land, of substances, preparations, organisms or micro-organisms.

The ELD provides for two liability regimes:

Under the first liability regime, operators of certain activities deemed to be of actual or potential concern, listed in Annex III to the ELD, can be held liable in the event of damage to protected species and natural habitats, water damage 
and land damage. Among the activities concerned, one shall find large industrial installations; waste management operations; certain installations releasing polluting substances into air; installations discharging polluting substances into water; manufacture, use, storage, processing, filling, release into the environment and onsite transport of dangerous substances and preparations; contained use of genetically modified micro-organisms and deliberate release into the environment, transport and placing on the market of genetically modified organisms.

\section{The Decree-Law $147 / 2008$ of July $29^{\text {th }}$}

The Decree-Law 147/2008, of 29 July came transpose into Portuguese law Directive 2004/35/EC of the European Parliament and of the Council of 21 April 2004. 1 March

Such legal rules was further amended by Decree-Law 245/2009 of 22 ${ }^{\text {th }}$ September and by Decree-Law 29-A/2011,

This law came into force in the Portuguese legal to August 1st $^{\text {t }}$ 2008. The national diploma establishes two distinct mechanisms of responsibility: i) liability and ii) administrative responsibility for the prevention and remedying of environmental damage-chapter II and III respectively.

In Chapter III set up mechanisms to prevent and repair damage to the environment before the collective, not the individual being reimbursed by virtue of such damages.

In Chapter III establishes to prevent and repair damage as mandatory, this is because whenever an operator causing environmental damage or threaten is legally and financially responsible for the repair and / or prevention.

The problem is that the legislature and as recognized in the preamble of the text had never been previously spun the difference between environmental damage and ecological damage: For many years the issue of environmental responsibility was considered in view of the damage caused to people and things.

The main problem consisted in repairing subsequent damage to environmental perturbations - i.e., the injuries suffered by a particular person in their legal interests or personality or in their assets as a result of environmental contamination. " Besides establishing two liability regimes: i) objective and ii) subjective. In strict liability the agent liable for the damage that resulted, being exempted from verification of the fault in his performance. From roughly this kind of responsibility will occur when we stand before the situations listed in Annex III of the diploma. All other operators are subject to subjective responsibility in the usual manner, ie, will have to verify the existence of a fact, wrongfulness, fault, damage and causal link between the fact and the damage.

\section{The non-application of the case law Decree-Law 147/2008}

The courts have not been called upon to rule on the application of this statute. Recently, the South Central Administrative Court was asked to rule on the basis of legal liability of the state's environmental, but still prior to the effectiveness of DL $147 / 2008$.

In this case, several associations representing fishing interests and environmental protection association of goshawks, brought an action for damages against the state for the purpose of claiming that it should oversee the subarea Azores Exclusive Economic Zone of Portugal, as well as payment of compensation to the plaintiffs for failure of supervision.

What was at issue here was that the Navy and Air Force Portuguese have omitted the required inspection activities conducted by vessels fishing for non-nationals, these prohibited between 100 and 200 miles, in the years 20022004, after the publication of the Council Regulation 1954/2003 of 4 November which only came into force on August 1 , 2004.

In fact, evidence that resulted in the Azores such supervision has always been done through the branches of the Navy and Air Force for many years and that the fisheries sector is responsible for employing four thousand people.

The existence of supervision has always functioned as a deterrent to the entry of vessels in that region and offenders between 2002 and 2004 were not made tours of inspection by the Navy and Air Force and moreover since the subarea of the Exclusive Economic Zone of the Azores has about one million square kilometres, never one of the branches of the armed forces without the other, together, can carry out effective supervision.

It was also established as a fact in the process that affects the means that the Portuguese navy also decreased the hours of supervision halved.

During the period more than 60 Spanish vessels fished in the area between 100 and 200 miles, which before the publication of the regulation only stood at twenty vessels. Besides that Spanish vessels have a capacity much higher 
than the fishing boats Azorean and endanger the maintenance of the normal amount of fish in the take up because all the fishing bank in question and prevent the Azorean fishing. Notwithstanding the statute in question does not apply, what is curious is that the judges we list it, particularly with regard to the concept of ecological damage, such as understanding the "injuries to natural ecological system and have not been tampered individual rights. It is a disorder in a natural element, i.e., an injury is caused to a natural resource, which could cause a significant allocation of the balance of the legal environment and natural heritage and their interaction. Only highlights the damage in natural element. The ecological damage has a certain degree of uncertainty as to their scope, of lack of scientific knowledge, but, according to the principle of prevention (art. 66, 2, CRP), the indeterminacy does not preclude there obligation repair, even if the damage be demonstrating. The repair may take two forms: fresh repair, which is subdivided into ecological restoration and ecological compensation and cash compensation (cash compensation). "Same option was followed with regard to the definition of environmental damage, since Judges understand that this is "that damage the environment that has repercussions in the sphere of a particular asset. Comprising the damage to property specific legal issues through private or through a set of emissions emanating from a set of emitters. " Conclude judges in decision under review "reflects an injury to legally protected rights and interests in the wake of the allocation of a particular environmental component." The court concludes by condemning the Portuguese state, once checked the requirements of responsibility: i) the existence of ecological damage, ii) conduct unlawful omission by the Portuguese state, and iii) a causal link and appropriate. In this regard and in relation to an application of Decree-Law 147/2008 in this case, Carla Amado Gomes, warning in Portuguese doctrine, that even if such a law were in force at the material time, the same would not apply, contrary to which suggests that the position would be followed by the court and that, because according to the author, the scope of diploma in crisis goes to the administration and not the courts.

\section{The articulation of D.L. 147/2008 with Law 67/2007}

The Portuguese Constitution, in article 22, instituted the general principle of tort liability of the State and other public law entities.

Consequently, ordinary legislation established the tort liability of the State into the Portuguese Legal Order, by means of Decree-Law 48051, of 1967.

This decree, which was criticised extensively, was amended by virtue of Law 67/2007, of 31st December, establishing the regime for tort liability arising from losses caused by third parties, due to the acts of public management in relation to all the functions of the State, i.e. i) administrative, ii) legislative, and iii) jurisdictional.

That decree was influenced by EU Law in the context of the framework applicable to tort liability arising from losses caused by administrative functions, as can be seen from its article 7, no. 2, which determines that in addition to the conditions established by domestic law, the "conditions for tort liability defined by EU law". This influence resulted in particular by Directive 89/665/EEC.

The administration's liability arises from action or the inaction of its bodies and agents and not from the fact that the Administration, in itself, causes losses.

The rule is that the administration is liable for the losses caused by its agents, if these occur in the performance of and as a result of their duties - functional actions - even in such situations when the action of those agents is culpable, or even wilful.

The strict liability of the administration raises two main questions: i) if the administration is solely liable or if jointly liable with the agents who caused the loss; ii) if the administration, after it has indemnified a loss, can then recover that amount from the agents by virtue of a right of recourse regarding all amounts paid.

In other words, it is necessary to ascertain whether the situation is a question of service fault or personal fault, seeing that with regard to the latter, if the action was performed while not performing duties, or during the performance of duties but not because of them, any liability would be borne by the employee or agent and not by the administration, according to that established in article 3, no. 1, of the abovementioned decree (Mendes, 2013), pp. 2260 e ss..

The regulations are of complementary application, as the Law 67/2007 applies at the level of judicial redress for damage, the DL 147/2008 applies preventively (Gomes, 2012), p. 333.

\section{References}

Gomes, Carla Amado. (2012). A responsabilidade civil extracontratual das entidades públicas e a responsailidade civil por dano ecológico: sobreposição ou complementaridade? Estudos em Homenagem ao Prof. Doutor José Joaquim Gomes Canotilho, 
Volume I - Responsabilidade entre Passado e Futuro.

Lawrence, D Grant. (2013). Environmental Liability Directive: A short Overview

Mendes, Jorge Barros. (2013). The tort liability of the state in the portuguese administrative courts. World Academy of science, engineering and techonology(78 june 2013 Paris), 2260.

Silva, Vasco Pereira da. (2000). Responsabilidade administrativa em matéria de ambiente. Lisboa: Principia. 